\title{
Vegetative and Reproductive Traits of Two Southern Highbush Blueberry Cultivars Grafted onto Vaccinium arboreum Rootstocks
}

\author{
Bruno Casamali, Rebecca L. Darnell ${ }^{1}$, Alisson P. Kovaleski, \\ James W. Olmstead, and Jeffrey G. Williamson \\ Horticultural Sciences Department, University of Florida, 1131 Fifield Hall, \\ Gainesville, FL 32611
}

Additional index words. grafting, Vaccinium corymbosum interspecific hybrid, sparkleberry, yield, fruit quality

\begin{abstract}
Vaccinium arboreum Marsh is a wild species adapted to high pH (above 6.0) and low organic matter soils (below $2.0 \%$ ). The use of $V$. arboreum rootstocks may be a viable option to increase soil adaptation of southern highbush blueberry (SHB) (Vaccinium corymbosum interspecific hybrid) under marginal soil conditions. The objective of this research was to evaluate the vegetative and reproductive traits of 'Farthing' and 'Meadowlark' SHB own-rooted or grafted onto $V$. arboreum and grown in pine barkamended or nonamended soil. The study was conducted from 2012 through 2014 at a research center in Citra, FL, and a grower's farm in Archer, FL. Vaccinium arboreum rootstock generally induced the same effects in both cultivars. Grafted plants in both soil treatments had reduced canopy growth in the first year after field planting compared with own-rooted plants in amended soil. However, canopy volume of grafted plants was greater than own-rooted plants in nonamended soil and similar to own-rooted plants in amended soil 2 years after field planting for 'Meadowlark' and 3 years after planting for 'Farthing'. Fruit yield was lower in grafted plants compared with own-rooted plants in the first fruiting year ( 2 years after field planting). By the second fruiting year, yields of grafted plants were similar to or greater than yields of own-rooted plants when grown in nonamended soil, whereas in amended soil, yields of grafted plants were similar to yields of own-rooted plants. Grafted plants had greater mean berry weight, but lower berry firmness; however, the firmness values were still considered acceptable (greater than 160 $\mathrm{g} \cdot \mathrm{mm}^{-1}$ ). Internal fruit quality [total soluble solids (TSS) and total titratable acidity (TTA)] was not consistently affected by the rootstock or soil treatments. These results suggest that grafting SHB onto $V$. arboreum does not increase yield in the establishment years compared with own-rooted SHB when grown in amended soils, but may have the ability to increase yield with no negative effects on fruit quality when grown in nonamended soils.
\end{abstract}

Cultivated Vaccinium species require specific soil conditions for establishment, vigorous plant growth, and fruit production. Soil adaptation of blueberry plants has been the subject of research over many years (Burkhard et al., 2009; Krewer et al., 2009; Strik and Buller, 2014). Soils suitable for blueberry production must be acidic $(\mathrm{pH} 4.0$ to 5.5), well aerated with good drainage, high in organic matter (Williamson et al., 2012), and have readily available iron $(\mathrm{Fe})$ and ammonium (Darnell and Hiss, 2006). To grow cultivated blueberry, including SHB, on typical agricultural soils (i.e., higher $\mathrm{pH}$

\footnotetext{
Received for publication 28 Apr. 2016. Accepted for publication 6 June 2016

This material is based upon work that is supported by the National Institute of Food and Agriculture, U.S. Department of Agriculture, under award number 2009-51181-06021 and by the Florida Department of Agriculture and Consumer Services award number 00120479 .

${ }^{1}$ Corresponding author. E-mail: rld@ufl.edu.
}

horticulture crops. Grafting has several benefits to plants, such as control of biotic and abiotic stresses (Liu et al., 2014), increased soil adaptation (Penella et al., 2015), and improved horticultural traits (Marra et al., 2013). Rootstocks may potentially impart several advantages to blueberries. Galleta and Fish Jr. (1971) reported that highbush cultivars grafted onto rabbiteye blueberry (Vaccinium virgatum Ait.) rootstocks exhibited greater plant height, flower bud number per shoot, and survival compared with own-rooted highbush cultivars ( $V$. corymbosum L.). Kunitake et al. (2006), testing different combinations of blueberry rootstocks (Vaccinium bracteatum Thunb. and $V$. virgatum) and scions ( $V$. corymbosum), found high survival rates in grafted plants and no signs of incompatibility between rootstock and scion, and speculated that blueberry grafting is possible for several varieties. $\mathrm{Xu}$ et al. (2014) found that 'Sharpblue' SHB grafted onto Wufanshu ( $V$. bracteatum) had greater plant height and yield than nongrafted plants; however, no differences were found for berry weight or fruit quality.

Vaccinium arboreum is a wild blueberry relative that is native to the southeastern United States. It grows in calcareous, sandy or sandy clay upland soils and tolerates soil $\mathrm{pH}$ up to 6.5, low organic matter (Lyrene, 1997), low Fe availability, and nitrogen in the form of nitrate $\left(\mathrm{NO}_{3}{ }^{-}\right)$(Darnell and Hiss, 2006) - conditions that V. corymbosum tolerates poorly. Studies have found that $\mathrm{NO}_{3}$ and $\mathrm{Fe}$ uptake are greater in $V$. arboreum compared with $V$. corymbosum (Darnell and Hiss, 2006; Poonnachit and Darnell, 2004), especially at high $\mathrm{pH}$ (Darnell, unpublished data). In addition, $V$. arboreum also has a deep root system, which increases drought tolerance (Lyrene, 1997).

Because of the wide soil adaptation and poor overall fruit quality of $V$. arboreum (Vander Kloet, 1988), previous studies have examined the use of $V$. arboreum as a rootstock for highbush blueberry. Ballington (1996) compared 'Premier' rabbiteye blueberry own-rooted vs. grafted onto $V$. arboreum and found that grafted plants had greater yield and fruit size than own-rooted plants, with no differences in fruit quality. In a later study also using $V$. arboreum, Ballington (1998) reported "superior" plant growth, fruit yield, and berry size of grafted 'Premier' compared with own-rooted plants; however, no significant differences were found in fruit flavor.

Vaccinium arboreum has the potential for use as a rootstock to expand blueberry production to soils with higher $\mathrm{pH}$ and low organic matter. Although there is information about soil adaptation of $V$. arboreum, as well as information on the use of $V$. arboreum as a rootstock in research trials, little is known about its performance when used as a rootstock in commercial field settings, under amended vs. nonamended soil conditions.

The hypothesis tested in this research was that SHB plants grafted onto $V$. arboreum rootstocks exhibit increased growth and yield 
compared with own-rooted SHB plants when grown in nonamended soil. The specific objectives were to evaluate the effects of soil treatment (pine bark-amended or nonamended soil) and root system (own-rooted or grafted plants) on plant growth, flower bud number, fruit number per inflorescence, fruit yield, berry weight, and fruit quality in two SHB cultivars.

\section{Materials and Methods}

Grafted and own-rooted 'Farthing' and 'Meadowlark' SHB were tested in two research plantings; one at the UF-IFAS Plant Science Research and Education Unit in Citra, FL, and the other at a commercial blueberry farm (Straughn Farms LLC, Archer, FL). Both cultivars are high yielding (Williamson et al., 2014), but they differ in plant architecture; 'Farthing' is bushy with many laterals (Lyrene, 2008), whereas 'Meadowlark' is tall and upright (Lyrene, 2010).

Four scion/rootstock combinations were grown at each site (own-rooted 'Farthing' or 'Meadowlark', and 'Farthing' or 'Meadowlark' grafted onto $V$. arboreum). Own-rooted plants were propagated by stem cuttings in Summer 2010 at a commercial nursery and maintained in 3.8-L pots until May 2011. Vaccinium arboreum seedlings used as rootstocks for grafted plants originated from two sources. The first source was seeds collected from open-pollinated $V$. arboreum plants in the forests of northeast Florida. Seeds were sown in Nov. 2008 and seedlings were transplanted to 96-cell trays of 1 peat : 1 perlite (by volume) in Feb. 2009. In May 2009, seedlings were transplanted to $11.4-\mathrm{L}$ pots containing 1 peat : 1 pine bark (by volume) and grown for 1 year. Additional $\approx 1$-year-old $V$. arboreum seedlings were purchased from a native plant nursery (Ornamental Plants and Trees, Inc., Hawthorne, FL) and transplanted to $11.4-\mathrm{L}$ pots containing 1 peat : 1 pine bark in May 2009. After May 2009, both seedling sources were maintained together.

Before grafting, $V$. arboreum rootstocks were selected and blocked for uniform vigor and stem diameter. Grafted plants were veneer-grafted in Summer 2010 and maintained in a greenhouse until scion growth occurred, when the rootstock was cut back just above the bud union. The experiments were field planted in May 2011, at which time the scion portions of the grafted plants were similar in size to the canopy of the ownrooted plants. Plants were spaced $0.9 \mathrm{~m}$ in the row by $3.0 \mathrm{~m}$ between rows in Citra, and $0.9 \mathrm{~m}$ in the row by $3.3 \mathrm{~m}$ between rows in Archer. Soil at both locations is Arredondo sand with low organic matter $(\approx 1.4 \%)$ and $\mathrm{pH} \approx 6.0$. Each scion/rootstock combination was grown in one of two soil treatments: 1) pine bark-amended soil and 2) nonamended soil. The amended soil treatment consisted of a homogeneous mixture of pine bark (primarily Pinus elliottii) and native soil, where a $10-\mathrm{cm}$ layer of pine bark was rototilled into the top $20 \mathrm{~cm}$ of the native soil, whereas the nonamended treatment consisted of native soil. At Citra, planting occurred on raised beds $(\approx 15 \mathrm{~cm}$ high and $\approx 90 \mathrm{~cm}$ wide $)$ to increase drainage. The planting at the Archer location was not on raised beds. The experiments were arranged in a split-plot design with soil treatments as main plots, and the scion/rootstock combinations as subplots. Main plots - which were different rows-were replicated six times in Citra, and four, six, or eight times in Archer, depending on the year and variable evaluated. Each subplot consisted of eight plants, with guard plants on each side and two data plants.

Irrigation, fertilization through drip irrigation, and pest management followed the recommended guidelines for blueberry production in Florida (Williamson and Lyrene, 1995; Williamson et al., 2013). Soil pH was kept between 5.0 and 6.0 using sulfuric acid $38 \%$ injected through the irrigation system. However, in Archer from Feb. to July 2013, soil $\mathrm{pH}$ increased to 6.3 due to problems with the acid injector. Plants had overhead irrigation for frost protection, which was used as necessary to protect buds, flowers, and developing fruit from freeze damage. On average, plants received an annual fertilizer rate of $213 \mathrm{~N}-21 \mathrm{P}-89 \mathrm{~K} \mathrm{~kg} \cdot \mathrm{ha}^{-1}$ and $762 \mathrm{~L}$ of irrigation water per plant in Citra, and $178 \mathrm{~N}-24 \mathrm{P}-75 \mathrm{~K} \mathrm{~kg} \cdot \mathrm{ha}^{-1}$ and $1290 \mathrm{~L}$ of irrigation water per plant in Archer. To maintain the soil $\mathrm{pH}$ in the target range, more irrigation water was needed in Archer than in Citra because of differences in the acid injection systems between the two sites. Irrigation water in Citra has high levels of calcium (61 ppm) and bicarbonate (237 ppm), and in Archer has very high levels of calcium (89 ppm) and high levels of bicarbonate (273 ppm). For both locations, $\approx 34 \%$ of the annual rate of fertilizer and water was applied from Jan. through June, 54\% from June through October, and 12\% applied from October to December. Foliar Fe (Dissolvine ${ }^{\circledR}$ E-Fe-13, AkzoNobel, Amsterdam, The Netherlands) was applied at a rate of $0.17 \mathrm{~kg} \cdot \mathrm{ha}^{-1}$ in Archer in Oct. 2013. Rootstock suckers were removed as needed before the summer of 2012, and then in the summer and fall of 2013 and 2014. Hydrogen cyanamide $(1.5 \%$ $\mathrm{v} / \mathrm{v})$ was applied late in Dec. 2012, 2013, and 2014, in Archer only. In the winter of 2013 and 2014, the most basal branches of all plants were removed to avoid contact with the ground. After harvest in June 2014, plants were top-pruned using a handheld hedger (PP2822, Poulan PRO, Charlotte, NC), reducing the maximum plant height to $\approx 150 \mathrm{~cm}$.

Plant canopy volume (PV) was measured at the end of the 2012 through 2014 growing seasons in Citra and Archer. Plant volume was determined using three plant measurements: 1) plant height $(H), 2$ ) plant diameter across the row $(D 1)$, and 3 ) plant diameter in row $(D 2)$. When D2 was greater than the inrow spacing $(90 \mathrm{~cm})$, the in-row spacing was used for the D2 value. Because of cultivar differences in canopy shape, the halfellipsoid equation, Eq. [1], was used for
'Farthing' and the elliptic cylinder equation, Eq. [2], was used for 'Meadowlark'.

$$
\begin{aligned}
& \mathrm{PV}_{\text {'Farthing' }}=\frac{2}{3} \times \pi \times H \times \frac{D 1}{2} \times \frac{D 2}{2} \\
& \mathrm{PV}_{\text {'Meadowlark' }}=\pi \times H \times \frac{D 1}{2} \times \frac{D 2}{2}
\end{aligned}
$$

After flower bud formation in Citra, flower bud count was performed by selecting one shoot per plant and counting total node number and flower bud number in the terminal $15 \mathrm{~cm}$ of the branch. Before harvest, in Mar. 2013 and Apr. 2014, fruit number per inflorescence was assessed using the shoots selected for flower bud count. Total berry number on each shoot was counted and fruit number per inflorescence was determined by dividing the total berry number by the flower bud number.

Fruit yield and mean berry weight were estimated from Mar. to June 2013 and 2014 in Citra and Archer. Berries were handharvested twice per week to avoid overripening and loss of berries. The cumulative total yield was determined at the end of the harvest season. Twenty-five berry subsamples were randomly selected from each plot at every harvest and weighed to determine mean berry weight. The harvest season was divided in three periods (early, mid, and late). The harvest dates of each period were combined to generate the mean berry weight of the period. The seasonal berry weight was calculated using a weighted average according to the berry yield of each period.

Fruit quality was assessed three times during the harvest season in 2013 and 2014 in Citra and Archer, by measuring fruit firmness, TSS, and TTA. Years were analyzed together for TSS, TTA, and TSS:TTA ratio since there were no year effects on these variables. The subsample of 25 berries previously selected for mean berry weight on a given date was used to determine berry firmness, TSS, and TTA. Berry firmness was measured with a fruit firmness tester (Model Firmtech 2; BioWorks, Wamego, KS) on the same day of harvest. Afterward, berries were frozen at $-30{ }^{\circ} \mathrm{C}$ until TSS and TTA analysis. Berries were thawed, macerated, and centrifuged at 14,636 $g_{\mathrm{n}}$ for $20 \mathrm{~min}$ (Model Sorvall Legend XTR; Thermo Scientific, Waltham, MA). The supernatant was filtered through cheese cloth to extract the juice. Total soluble solids were assessed using a refractometer (Model AR200 or Model R²I300; Reichert, Depew, NY) and expressed as ${ }^{\circ}$ Brix. Total titratable acidity (expressed as \% citric acid) was assessed using an automated titrator (Model 719 S Tritino or Model 901 Titrando; Metrohm, Riverview, FL), titrating $6 \mathrm{~mL}$ of juice diluted in $50 \mathrm{~mL}$ of deionized water with $0.1 \mathrm{~N} \mathrm{NaOH}$ to an endpoint of $\mathrm{pH}$ 8.2. The TSS:TTA ratio was calculated to express the maturation index of the berries.

Since the plants were young and had not reached mature size and stable production during the course of the experiment, data from each year were analyzed separately 
(with the exception of TSS, TTA, and TSS: TTA) to identify only the treatment effects. Each cultivar was evaluated separately because of the different growth habits, and each location was evaluated separately because of the differences in soil and water characteristics. SAS 9.2 (SAS Institute Inc., Cary, NC) was used to compare treatment means and interactions, using PROC GLIMMIX. Means were separated using Tukey's honestly significant difference test at $P \leq 0.05$. $P$ values smaller than 0.001 were rounded to 0.001 .

\section{Results}

Citra. Own-rooted 'Farthing' grown in pine bark-amended soil had larger canopy volume than grafted plants grown in either soil treatment or own-rooted plants grown in nonamended soil at the end of the 2012 and 2013 growing seasons (Table 1). This was true for 'Meadowlark' in 2012; however, in 2013, own-rooted 'Meadowlark' grown in pine bark-amended soil or grafted plants grown in either soil treatment had larger canopy volume than own-rooted plants grown in nonamended soil. At the end of the 2014 growing season, there were no interactions between root and soil system for either cultivar. Plants grown in amended soil had greater canopy volume than plants grown in nonamended soil $\left(1.70 \mathrm{vs} .1 .08 \mathrm{~m}^{3}\right.$, respectively, for 'Farthing', $P=0.029$ ) and 1.31 vs. $0.90 \mathrm{~m}^{3}$, respectively, for 'Meadowlark', $P=0.001)$. Grafted 'Meadowlark' plants had greater canopy volume than ownrooted plants (1.79 vs. $\left.1.22 \mathrm{~m}^{3}, P=0.001\right)$, but there was no difference in canopy volume of grafted vs. own-rooted 'Farthing' $\left(\approx 0.99 \mathrm{~m}^{3}, P=0.520\right)$.

Neither flower buds per node nor fruit number per inflorescence were affected by root or soil treatments in 'Farthing' in either 2013 or 2014 (flower buds per node: root treatment, 2013, $P=0.555$; root treatment, 2014, $P=0.549$; soil treatment, 2013, $P=$ 0.324 ; soil treatment, $2014, P=0.409$; fruit number per inflorescence: root treatment, 2013, $P=0.108$; root treatment, 2014, $P=$ 0.195 ; soil treatment, $2013, P=0.168$; soil treatment, 2014, $P=0.109$ ). For 'Meadowlark', there was a significant interaction between root and soil treatments on flower buds per node in $2013(P=0.045)$ and fruit number per inflorescence in $2014(P=$ 0.043 ). Own-rooted plants grown in amended soil had the greatest flower bud number per node ( 0.58$)$, followed by own-rooted plants in nonamended soil (0.46), and followed by grafted plants in either soil treatment $(\approx 0.36)$. Grafted 'Meadowlark' in amended soil had greater fruit number per inflorescence (4.98), followed by own-rooted or grafted plants in nonamended soil $(\approx 3.91)$, which was followed by own-rooted plants in amended soil (2.86).

In 2013, own-rooted plants grown in pine bark-amended soil had greater yield than grafted plants grown in either soil treatment or own-rooted plants grown in nonamended soil for both cultivars (Table 2). However, in

Table 1. Effect of root and soil treatments on canopy volume of 'Farthing' and 'Meadowlark' southern highbush blueberry from 2012 to 2014, Citra and Archer, FL.

\begin{tabular}{|c|c|c|c|c|c|c|}
\hline \multirow[b]{3}{*}{ Treatment $^{2}$} & \multicolumn{6}{|c|}{ Canopy volume $\left(\mathrm{m}^{3}\right)$} \\
\hline & \multicolumn{3}{|c|}{ Farthing } & \multicolumn{3}{|c|}{ Meadowlark } \\
\hline & 2012 & 2013 & 2014 & 2012 & 2013 & 2014 \\
\hline \multicolumn{7}{|c|}{ Citra } \\
\hline Own-rooted/amended & $0.8 \mathrm{a}^{\mathrm{y}}$ & $0.9 \mathrm{a}$ & 1.1 & $0.7 \mathrm{a}$ & $1.0 \mathrm{a}$ & 1.5 \\
\hline Own-rooted/nonamended & $0.5 \mathrm{~b}$ & $0.6 \mathrm{~b}$ & 0.9 & $0.4 \mathrm{~b}$ & $0.6 \mathrm{~b}$ & 1.0 \\
\hline Grafted/amended & $0.3 \mathrm{~b}$ & $0.6 \mathrm{~b}$ & 1.0 & $0.5 \mathrm{~b}$ & $1.1 \mathrm{a}$ & 2.0 \\
\hline Grafted/nonamended & $0.4 \mathrm{~b}$ & $0.6 \mathrm{~b}$ & 0.9 & $0.4 \mathrm{~b}$ & $1.0 \mathrm{a}$ & 1.6 \\
\hline \multicolumn{7}{|l|}{$P$ values } \\
\hline $\operatorname{Root}^{x}$ & 0.001 & 0.001 & 0.520 & 0.088 & 0.001 & 0.001 \\
\hline Soil & 0.039 & 0.001 & 0.029 & 0.004 & 0.001 & 0.001 \\
\hline Root $\times$ Soil & \multicolumn{5}{|c|}{ Archer } & 0.460 \\
\hline Own-rooted/amended & $0.8 \mathrm{a}$ & $1.0 \mathrm{a}$ & $1.0 \mathrm{a}$ & $0.9 \mathrm{a}$ & $1.2 \mathrm{a}$ & $1.1 \mathrm{a}$ \\
\hline Own-rooted/nonamended & $0.4 \mathrm{~b}$ & $0.5 \mathrm{c}$ & $0.6 \mathrm{~b}$ & $0.4 \mathrm{~b}$ & $0.5 \mathrm{c}$ & $0.5 \mathrm{~b}$ \\
\hline Grafted/amended & $0.4 \mathrm{~b}$ & $0.8 \mathrm{~b}$ & $1.0 \mathrm{a}$ & $0.5 \mathrm{~b}$ & $1.1 \mathrm{a}$ & $1.1 \mathrm{a}$ \\
\hline Grafted/nonamended & $0.4 \mathrm{~b}$ & $0.5 \mathrm{c}$ & $0.8 \mathrm{a}$ & $0.4 \mathrm{~b}$ & $0.8 \mathrm{~b}$ & $0.9 \mathrm{a}$ \\
\hline \multicolumn{7}{|l|}{$P$ values } \\
\hline Root & 0.001 & 0.019 & 0.084 & 0.001 & 0.090 & 0.001 \\
\hline Soil & 0.001 & 0.001 & 0.001 & 0.001 & 0.001 & 0.001 \\
\hline Root $\times$ Soil & 0.001 & 0.001 & 0.007 & 0.001 & 0.008 & 0.001 \\
\hline
\end{tabular}

${ }^{\mathrm{z}}$ Own-rooted = cultivars grown on their own roots; grafted = cultivars grafted onto Vaccinium arboreum rootstock; amended = pine bark-amended soil; nonamended = native soil.

${ }^{y}$ Means represent the root $\times$ soil interaction. Means followed by the same letter within a column and location are not significantly different by Tukey's honestly significant difference, $P \leq 0.05$. Means without letters indicate the root $\times$ soil interaction was not significant.

${ }^{\mathrm{x}}$ Main effect means for root (own-rooted vs. grafted) and soil (amended vs. nonamended) are not given, but $P$ values indicate significance.

2014, the root by soil interaction was not significant for either cultivar. For 'Farthing', plants grown in amended soil yielded more (4476 g/plant) than plants grown in nonamended soil (3746 g/plant), whereas there was no difference in yield between ownrooted (4423 g/plant) and grafted plants (3799 g/plant). 'Meadowlark' grown in amended soil also yielded more $(4260 \mathrm{~g} /$ plant) than in nonamended soil (3216 g/ plant); however, in contrast to 'Farthing', grafted 'Meadowlark' plants had greater yields (4095 g/plant) than own-rooted plants (3381 g/plant).

In 2013, root treatment significantly affected berry weight of 'Farthing' during early season (14 Mar. to $15 \mathrm{Apr}$.), where average berry weight of grafted plants averaged $2.28 \mathrm{~g}$ compared with $2.54 \mathrm{~g}$ for own-rooted plants (Table $3, P=0.006$ ). Soil treatments significantly affected berry weight of 'Farthing' only during late season (16 May to 3 June) (Table 3) where berry size averaged $1.72 \mathrm{~g}$ and $1.53 \mathrm{~g}$ for amended and nonamended soils, respectively $(P=0.010)$. However, seasonal berry weight was not significantly affected by root or soil treatments. Berry weight of grafted 'Meadowlark' was greater than own-rooted plants throughout the season (early, mid, and late season); however, soil treatment did not significantly affect mean berry weight. However, significant interactions between root and soil were found for midseason and seasonal berry weight (Table 3 ).

In 2014, berry weight of grafted 'Farthing' was greater than that of own-rooted plants during midseason (16 Apr. to 15 May) (Table 3, $\mathrm{P}=0.042$ ) and for the overall season mean (Table 3, P = 0.041). For 'Meadowlark', interactions between root and soil treatments were found for most of the periods evaluated and the season average, where grafted plants in either soil treatment or own-rooted plants in nonamended soil generally had greater berry weight than ownrooted plants in amended soil.

In general, fruit firmness was greater in own-rooted compared with grafted 'Farthing' in both years ( 253 vs. $245 \mathrm{~g} \cdot \mathrm{mm}^{-1}, P=0.006$, and 220 vs. $201 \mathrm{~g} \cdot \mathrm{mm}^{-1}, P=0.001$, in 2013 and 2014, respectively); however, soil treatments generally did not affect berry firmness. For 'Meadowlark', fruit firmness was similar among treatments in 2013; however, significant root by soil interactions were found in $2014(P=0.006)$. Generally, berries from own-rooted plants in amended soil had greater firmness $\left(254 \mathrm{~g} \cdot \mathrm{mm}^{-1}\right)$ than berries from own-rooted plants in nonamended soil (241 $\left.\mathrm{g} \cdot \mathrm{mm}^{-1}\right)$, followed by grafted plants in either soil treatment $\left(\approx 226 \mathrm{~g} \cdot \mathrm{mm}^{-1}\right)$.

Years were analyzed together for TSS, TTA, and TSS:TTA ratio since there were no year effects on these variables. Fruit from 'Farthing' own-rooted plants had greater TTA than fruit from grafted plants $(0.57 \%$ vs. $0.54 \%$ citric acid, $P=0.019$ ); however, soil treatments did not significantly affect TTA. Total soluble solids were unaffected by root or soil treatments. The maturation index (TSS:TTA ratio) was greater for early and midseason berries from grafted plants compared with own-rooted plants (23.2 vs. 21.7 for early season, $P=0.042$ and 19.9 vs. 18.1 for midseason, $P=0.047$ ), but was unaffected by root treatment. For 'Meadowlark', root treatments did not affect berry TTA, and berries from nonamended soil had greater TTA than those in amended soil $(0.43 \%$ vs. $0.40 \%$ citric acid, $P=0.028$ ). No significant treatment differences in fruit TSS were found. Fruit from plants in amended soil 
generally had a greater maturation index than those in nonamended soil ( 27.2 vs. $24.7, P=$ 0.012 ); however, root treatments did not affect maturation index.

Archer. At the end of the 2012 growing season, own-rooted plants in amended soil had greater canopy volume than own-rooted plants in nonamended soil or grafted plants in either soil treatment for both cultivars (Table 1). By the end of the 2013 season, own-rooted 'Farthing' in amended soil had the greatest canopy volume, followed by grafted plants in amended soil, followed by own-rooted or grafted plants in nonamended soil. For 'Meadowlark', own-rooted or grafted plants in amended soil had greater canopy volume than grafted plants in nonamended soil, which was greater than ownrooted plants in nonamended soil. At the end of the 2014 season, grafted plants in either

Table 2. Effect of root and soil treatments on total yield in 'Farthing' and 'Meadowlark' southern highbush blueberry in 2013 and 2014, Citra and Archer, FL.

\begin{tabular}{|c|c|c|c|c|}
\hline \multirow[b]{3}{*}{ Treatment $^{2}$} & \multicolumn{4}{|c|}{ Total yield (g/plant) } \\
\hline & \multicolumn{2}{|c|}{ Farthing } & \multicolumn{2}{|c|}{ Meadowlark } \\
\hline & 2013 & 2014 & 2013 & 2014 \\
\hline \multicolumn{5}{|c|}{ Citra } \\
\hline Own-rooted/amended & $4,731 \mathrm{a}^{\mathrm{y}}$ & 4,837 & $2,789 \mathrm{a}$ & 4,052 \\
\hline Own-rooted/nonamended & $2,222 \mathrm{~b}$ & 4,008 & $1,451 \mathrm{~b}$ & 2,710 \\
\hline Grafted/amended & $1,954 \mathrm{~b}$ & 4,114 & $1,955 \mathrm{~b}$ & 4,468 \\
\hline Grafted/nonamended & $1,933 \mathrm{~b}$ & 3,484 & $1,759 \mathrm{~b}$ & 3,722 \\
\hline \multicolumn{5}{|l|}{$P$ values } \\
\hline $\operatorname{Root}^{x}$ & 0.001 & 0.059 & 0.185 & 0.033 \\
\hline Soil & 0.001 & 0.028 & 0.004 & 0.014 \\
\hline Root $\times$ Soil & 0.001 & 0.753 & 0.011 & 0.328 \\
\hline \multicolumn{5}{|c|}{ Archer } \\
\hline Own-rooted/amended & $5,192 \mathrm{a}$ & $4,943 \mathrm{a}$ & $3,323 \mathrm{a}$ & $5,036 \mathrm{a}$ \\
\hline Own-rooted/nonamended & $1,980 \mathrm{~b}$ & $1,927 \mathrm{c}$ & $1,418 \mathrm{~b}$ & $1,715 \mathrm{c}$ \\
\hline Grafted/amended & $2,568 \mathrm{~b}$ & $4,298 \mathrm{ab}$ & $1,281 \mathrm{~b}$ & $2,792 \mathrm{bc}$ \\
\hline Grafted/nonamended & $2,009 \mathrm{~b}$ & $3,263 \mathrm{~b}$ & $1,679 \mathrm{~b}$ & $3,323 \mathrm{~b}$ \\
\hline \multicolumn{5}{|l|}{$P$ values } \\
\hline Root & 0.001 & 0.254 & 0.014 & 0.347 \\
\hline Soil & 0.007 & 0.001 & 0.071 & 0.001 \\
\hline Root $\times$ Soil & 0.001 & 0.003 & 0.004 & 0.001 \\
\hline
\end{tabular}

${ }^{\mathrm{z}}$ Own-rooted $=$ cultivars grown on their own roots; grafted = cultivars grafted onto Vaccinium arboreum; amended $=$ pine bark-amended soil; nonamended $=$ native soil .

${ }^{y}$ Means represent the root $\times$ soil interaction. Means followed by the same letter within a column and location are not significantly different by Tukey's honestly significant difference, $P \leq 0.05$. Means without letters indicate the root $\times$ soil interaction was not significant.

${ }^{x}$ Main effect means for root (own-rooted vs. grafted) and soil (amended vs. nonamended) are not given, but $P$ values indicate significance. soil treatment or own-rooted plants in amended soil had greater canopy volume than own-rooted plants in nonamended soil for both cultivars.

In 2013, own-rooted plants of both cultivars in amended soil yielded more than ownrooted plants in nonamended soil or grafted plants in either soil treatment (Table 2). In 2014, yields of own-rooted and grafted 'Farthing' in amended soil were similar, whereas own-rooted 'Meadowlark' in amended soil yielded more than grafted 'Meadowlark' in either soil treatment. For both cultivars, yields of grafted plants were greater than own-rooted plants when grown in nonamended soil.

In general, berry weight in 2013 was greater for own-rooted plants in amended soil and grafted plants in either soil treatment during the three harvest periods compared with berries from own-rooted plants in nonamended soil for both cultivars (Table 4). A similar, although not statistically significant trend, was observed for the season average berry weight of 'Farthing' $(P=0.109)$. In 2014, treatment effects on berry weight of 'Farthing' throughout the season were similar to 2013; however, season average berry weight was lowest for own-rooted 'Farthing' in nonamended soil and highest for grafted 'Farthing' in either soil treatment. For 'Meadowlark', no interactions between root and soil treatments were observed in 2014. Berry weight of grafted plants was significantly greater than berry weight of own-rooted plants and berry weight of plants grown in amended soil were greater than berry weight of plants grown in nonamended soil throughout the harvest season (Table 4).

Table 3. Effect of root and soil treatments on mean berry weight of 'Farthing' and 'Meadowlark' southern highbush blueberry in each harvest period and averaged over the season in 2013 and 2014, Citra, FL.

\begin{tabular}{|c|c|c|c|c|c|c|c|c|}
\hline \multirow{2}{*}{ Treatment $^{\mathrm{z}}$} & \multicolumn{8}{|c|}{ Berry weight $(\mathrm{g})$} \\
\hline & \multicolumn{4}{|c|}{2013} & \multicolumn{4}{|c|}{2014} \\
\hline & & & Farthing & & & & & \\
\hline Own-rooted/nonamended & 2.58 & 2.43 & 1.52 & 2.28 & 1.76 & 1.99 & 1.28 & 1.84 \\
\hline Grafted/amended & 2.24 & 2.40 & 1.74 & 2.27 & 1.97 & 2.18 & 1.53 & 2.05 \\
\hline \multirow{2}{*}{\multicolumn{9}{|c|}{$P$ values }} \\
\hline & & & & & & & & \\
\hline \multirow[t]{2}{*}{ Root $\times$ Soil } & 0.972 & 0.599 & 0.849 & 0.667 & 0.284 & 0.910 & 0.455 & 0.531 \\
\hline & & & Meadowlark & & & & & \\
\hline Own-rooted/amended & 2.33 & $2.36 \mathrm{c}^{\mathrm{w}}$ & 1.47 & $2.34 \mathrm{~b}$ & $1.75 \mathrm{~b}$ & $1.83 \mathrm{~b}$ & 1.04 & $1.79 \mathrm{~b}$ \\
\hline Own-rooted/nonamended & 2.52 & $2.35 \mathrm{c}$ & 1.25 & $2.40 \mathrm{~b}$ & $2.25 \mathrm{a}$ & $2.12 \mathrm{a}$ & 1.01 & $2.12 \mathrm{a}$ \\
\hline Grafted/amended & 2.54 & $2.65 \mathrm{a}$ & 1.89 & $2.60 \mathrm{a}$ & $2.30 \mathrm{a}$ & $2.30 \mathrm{a}$ & 1.36 & $2.25 \mathrm{a}$ \\
\hline Grafted/nonamended & 2.57 & $2.51 \mathrm{~b}$ & 1.72 & $2.51 \mathrm{a}$ & $2.28 \mathrm{a}$ & $2.23 \mathrm{a}$ & 1.30 & $2.21 \mathrm{a}$ \\
\hline \multicolumn{9}{|l|}{$P$ values } \\
\hline
\end{tabular}

${ }^{\mathrm{z}}$ Own-rooted = cultivars grown on their own roots; grafted = cultivars grafted onto Vaccinium arboreum $;$ amended = pine bark-amended soil; nonamended = native soil.

${ }^{\mathrm{y}}$ Harvest periods for 2013: 14 Mar.-15 Apr. is early season, 16 Apr.-15 May is midseason, and 16 May-3 June is late season. For 2014: 7-15 Apr. is early season, 16 Apr.-15 May is midseason, and 16 May-2 June is late season. Seasonal berry weight was calculated using a weighted average according to the berry yield of each period.

${ }^{x}$ Main effect means for root (own-rooted vs. grafted) and soil (amended vs. nonamended) are not given, but $P$ values indicate significance.

"Means represent the root $\times$ soil interaction. Means followed by the same letter within a column and cultivar are not significantly different by Tukey's honestly significant difference, $P \leq 0.05$. Means without letters indicate the root $\times$ soil interaction was not significant. 
Table 4. Effect of root and soil treatments on mean berry weight of 'Farthing' and 'Meadowlark' southern highbush blueberry in each harvest period and averaged over the season in 2013 and 2014, Archer, FL.

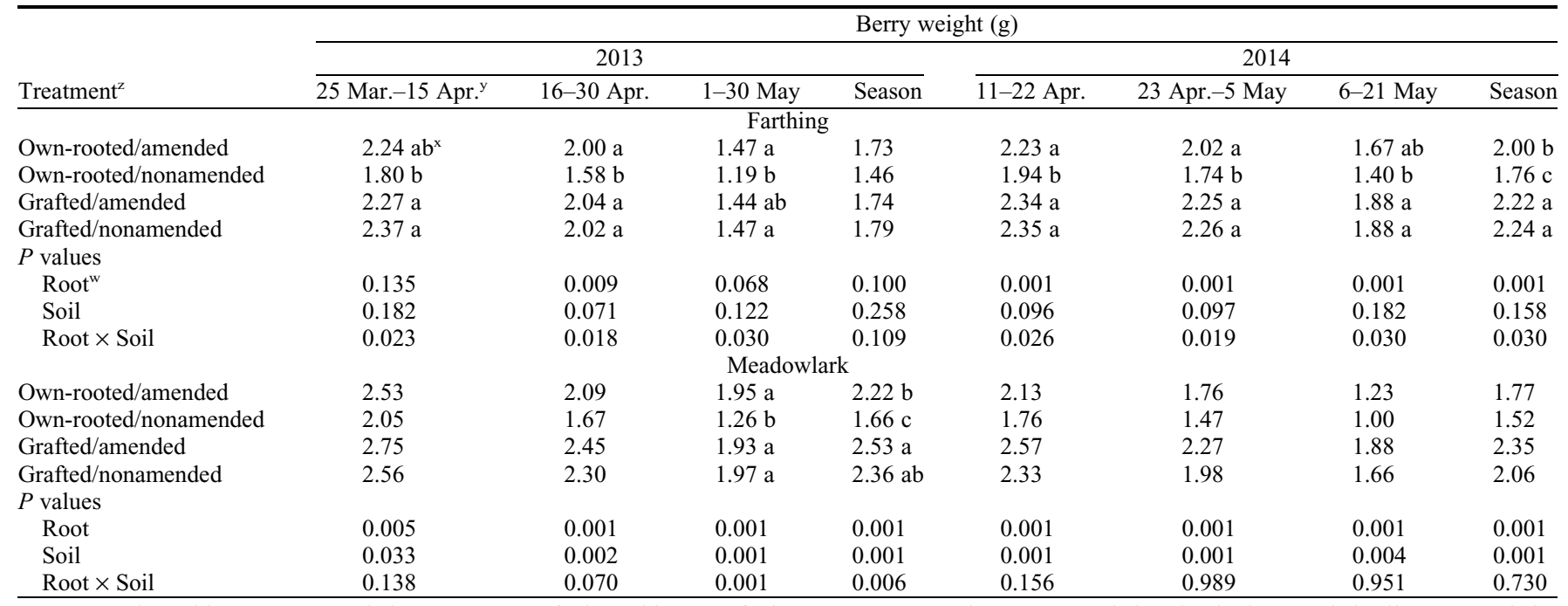

${ }^{\mathrm{z}}$ Own-rooted $=$ cultivars grown on their own roots; grafted = cultivars grafted onto Vaccinium arboreum $;$ amended = pine bark-amended soil; nonamended $=$ native soil.

${ }^{\mathrm{y}}$ Harvest periods for 2013: 25 Mar.-15 Apr. is early season, 16-30 Apr. is midseason, and 1-30 May is late season. For 2014: 11-22 Apr. is early season, 23 Apr.-5 May is midseason, and 6-21 May is late season. Seasonal berry weight was calculated using a weighted average according to the berry yield of each period. ${ }^{x}$ Means represent the root $\times$ soil interaction. Means followed by the same letter within a column and cultivar are not significantly different by Tukey's honestly significant difference, $P \leq 0.05$. Means without letters indicate the root $\times$ soil interaction was not significant.

${ }^{\text {w} M a i n ~ e f f e c t ~ m e a n s ~ f o r ~ r o o t ~(o w n-r o o t e d ~ v s . ~ g r a f t e d) ~ a n d ~ s o i l ~(a m e n d e d ~ v s . ~ n o n a m e n d e d) ~ a r e ~ n o t ~ g i v e n, ~ b u t ~} P$ values indicate significance.

Root treatments did not substantially affect berry firmness of 'Farthing' in 2013 (data not shown); however, own-rooted 'Meadowlark' plants had greater berry firmness than grafted 'Meadowlark' plants late in the season ( 253 vs. $\left.238 \mathrm{~g} \cdot \mathrm{mm}^{-1}, P=0.009\right)$, and for the overall season $\left(250\right.$ vs. $237 \mathrm{~g} \cdot \mathrm{mm}^{-1}, P=$ $0.007)$. In 2014, overall season berry firmness of own-rooted plants was generally greater compared with grafted plants for 'Farthing' (231 vs. $212 \mathrm{~g} \cdot \mathrm{mm}^{-1}, P=0.001$ ) and 'Meadowlark' (243 vs. $231 \mathrm{~g} \cdot \mathrm{mm}^{-1}, P=0.001$ ). Soil treatments did not affect berry firmness for either year.

In general, overall season TSS were greater in fruit from own-rooted 'Farthing' compared with grafted plants (12.3 vs. 11.7 ${ }^{\circ}$ Brix, $\left.P=0.001\right)$, but there were no effects on TTA or TSS:TTA. For 'Meadowlark', fruit from grafted plants generally had greater TTA $(0.35 \%$ vs. $0.28 \%$ citric acid, $P=$ $0.001)$ and TSS (11.1 vs. $10.4{ }^{\circ}$ Brix, $P=$ $0.001)$, compared with own-rooted plants during the season, but there were no effects on TSS:TTA. Soil treatments did not affect fruit quality of either cultivar.

\section{Discussion}

For both locations, grafted plants in both soil treatments initially had reduced canopy growth compared with own-rooted plants in amended soil. This may have been due to the grafting process itself. The graft union is formed after a sequence of complex processes and grafting has been reported to reduce initial growth (Turnbull et al., 2002), and delay flower formation and yield (Khah et al., 2006) in herbaceous plants compared with own-rooted plants. At the end of the third growing season (2014) in our study, PV of grafted plants was similar to ('Farthing') or larger ('Meadowlark') than canopy volume of own-rooted plants. This highlights the greater vigor of grafted vs. own-rooted 'Meadowlark' during 2014, since both grafted and own-rooted plants were pruned to about equal canopy volume in June 2014. Effects of different Vaccinium rootstocks on blueberry growth have been described previously. Ballington (1998) reported "superior" growth of 'Premier' rabbiteye blueberry grafted onto $V$. arboreum compared with own-rooted plants after the first year of field planting, although no quantitative data on growth were presented. Kunitake et al. (2006) reported that 'Earliblue' northern highbush blueberry grafted onto 'Shashambo' ( $V$. bracteatum) or $V$. virgatum rootstocks exhibited increased shoot extension compared with own-rooted 'Earliblue'. Our work with 'Meadowlark' supports these previous reports, where canopy volume of grafted plants exceeded those of own-rooted plants. However, canopy volume of grafted 'Farthing' did not exceed that of own-rooted plants. Furthermore, neither Ballington (1998) nor Kunitake et al. (2006) reported an initial reduction in growth, as we observed the first 3 years after field planting. This may be due to different effects of scion/rootstock combinations, use of older grafted plants in the previous work, and/or differences in the grafting technique.

Vaccinium arboreum, when used as rootstock, appears to have few negative impacts on growth of the scion. In particular, canopy volumes of grafted plants in nonamended soil were similar to those of own-rooted plants in amended soil after the third growing season (2014), suggesting that grafting SHB onto
$V$. arboreum rootstocks does indeed confer increased tolerance to nonamended soils compared with own-rooted plants. To our knowledge, this is the first work describing the possible effects of blueberry rootstocks in nonamended soils, distinct from Ballington (1998) and $\mathrm{Xu}$ et al. (2014), who tested grafted blueberry in amended soil only. The increased tolerance to nonamended soil may be due to the tolerance to low organic matter exhibited by $V$. arboreum (Lyrene, 1997). This, combined with greater nitrate and Fe uptake (Darnell and Hiss, 2006) and a deeper root system (Lyrene, 1997) in V. arboreum compared with $V$. corymbosum, may impart increased adaptability in grafted compared with own-rooted plants in our study. On the other hand, canopy volumes of own-rooted plants in nonamended soil were consistently smaller compared with own-rooted plants in amended soil, and were also generally smaller than grafted plants in either soil treatment. Similar results were found by Burkhard et al. (2009), who reported greater plant vigor and canopy volume in own-rooted blueberry grown in mulched vs. nonmulched soils.

The reduction in fruit yield of grafted plants the first fruiting year (2013) was likely due to the initial reduction in growth due to the grafting process. However, after growth recovery from grafting, $V$. arboreum rootstocks induced similar or greater yields in SHB than own-rooted SHB regardless of soil treatment (Citra) or when grown in nonamended soil (Archer). The different location effects may have been due to the greater decrease in canopy volume and therefore yield in own-rooted plants grown in nonamended vs. amended soil in Archer compared with Citra. In Archer, canopy volume 
of own-rooted plants on nonamended soil was $\approx 55 \%$ smaller than own-rooted plants grown on amended soil at the end of the 2013 growing season, whereas in Citra, canopy volume of own-rooted plants in nonamended soil was $\approx 37 \%$ smaller compared with ownrooted plants grown on amended soil. It is likely that the high levels of calcium and bicarbonates in the irrigation water at Archer reduced canopy growth of own-rooted blueberry plants (Williamson and Lyrene, 1995) when no soil amendments were used. This, combined with the period when acid was not applied in Archer (Feb. to July 2013), may have increased the negative impact of nonamended soils on own-rooted plants in Archer compared with Citra.

There was a strong linear correlation between PV and fruit yield across locations, years, cultivars, root, and soil treatments $\left(R^{2}=0.60, P=0.001\right)$. This is in agreement with previous work (Krewer et al., 2009; Williamson and Miller, 2009), where blueberry yields were higher in plants with greater canopy volume. Canopy volume at the end of the previous season explained $\approx 70 \%$ of the variability in yield in both cultivars and locations in 2013; however, in 2014 , only $\approx 50 \%$ of the variability in yield was explained by canopy volume. Thus, as plants increased in canopy size, the correlation between canopy volume and yield was weakened. For 'Farthing', this was likely due to the plant architecture, which consists of many internal shoots that increase in number with successive growing seasons. These internal shoots would not increase canopy volume; however, they would potentially increase fruiting shoots inside the plant. For 'Meadowlark', the increased number of fruits per inflorescence bud found in grafted plants compared with own-rooted plants would be an additional source of variability in yield, thus reducing the correlation between canopy volume and yield. This supports work by Retamales et al. (2008), who reported a positive correlation between fruit number per inflorescence and yield in blueberry. Rootstocks have also been reported to affect fruit number per inflorescence in other fruit crops, including citrus (Pérez-Pérez et al., 2008) and apple (Webster, 1995).

Mean berry weight varied considerably between field locations and cultivars. Previous work report differences in mean berry weight due to different factors, such as pruning (Kovaleski et al., 2015), seed number per berry (Harrison et al., 1993), source:sink ratio (Maust et al., 1999), and pollination (Bell et al., 2010). In Citra, differences in mean berry weight were cultivar dependent. Although no major differences were found for 'Farthing', berries from own-rooted 'Meadowlark' plants, especially when grown in amended soil, tended to be smaller than berries from grafted plants. Similar results were found by Ballington (1998) for 'Premier' rabbiteye blueberry grafted onto $V$. arboreum vs. own-rooted 'Premier'. Ballington speculated that the drought-tolerant root system of $V$. arboreum resulted in a better water status for grafted vs. own-rooted plants, which resulted in increased berry size. Kunitake et al. (2006) found that 'Earliblue' grafted onto $V$. bracteatum or rabbiteye blueberry rootstocks had larger berries compared with own-rooted 'Earliblue'. In contrast, no differences in berry weight were found by $\mathrm{Xu}$ et al. (2014) testing grafted plants of 'Sharpblue' onto $V$. bracteatum vs. own-rooted plants.

Berry size of own-rooted 'Farthing' and 'Meadowlark' in nonamended soil was smaller compared with the other treatments at the Archer location. This may be related to the reduced canopy volume of these plants. The high levels of $\mathrm{Ca}$ and bicarbonate found in the irrigation water in Archer, combined with the transient increase in soil $\mathrm{pH}(6.0$ 6.3) from Feb. to July 2013, decreased plant growth, particularly in nonamended soils. The reduced canopy volume may decrease availability of carbohydrates for fruit development (Maust et al., 1999), potentially decreasing berry weight, supporting work by Kovaleski et al. (2015), who reported reduction in mean berry weight in plants that had $60 \%$ of the canopy removed compared with nonpruned plants.

The general decrease in berry firmness found in grafted vs. own-rooted plants may be a result of the larger berry size found in grafted plants. Ballington (1998) found that 'Premier' blueberry grafted onto $V$. arboreum had increased berry size and reduced berry firmness compared with own-rooted plants, speculating that the increased water uptake exhibited by $V$. arboreum may result in reduced berry firmness. Although berry firmness of grafted plants decreased compared with own-rooted plants, values of firmness were still considered acceptable for blueberry, as reported by Ehlenfeldt and Martin (2002).

Vaccinium arboreum rootstocks did not consistently affect internal fruit quality traits, which was similar to results from Ballington (1998). Xu et al. (2014), who tested a different species of rootstock for blueberries, also reported no differences in internal fruit quality. However, scion/rootstock combinations play an important role in determining fruit quality in fruit (Cantuarias-Avilés et al., 2010) and vegetable crops (Davis et al., 2008), thus, additional studies may be needed to determine if using $V$. arboreum as a rootstock impacts fruit quality in other blueberry cultivars.

Effects of $V$. arboreum rootstocks on SHB generally followed the same trend for both cultivars tested. The grafting process initially reduced canopy growth and decreased yield in the first fruiting year (2013) compared with own-rooted plants in amended soil. Three years after planting (2014), plants grafted onto $V$. arboreum rootstocks and grown in nonamended soil were larger than ownrooted plants in nonamended soil and similar in size to own-rooted and grafted plants in amended soil. Yield differences between grafted and own-rooted plants were inconsistent. Yields were generally greater in grafted plants vs. own-rooted plants when grown in nonamended soil, whereas yields were similar when grown in amended soil. Plants grafted onto $V$. arboreum rootstocks had greater mean berry weight than own-rooted plants, which generally decreased berry firmness; however, firmness values were still within the acceptable range for marketable blueberry fruit. Internal fruit quality was unaffected by the rootstock. These results suggest that grafting SHB onto $V$. arboreum rootstocks may enable a reduction in the use of soil amendments for commercial production systems, without negative impacts on fruit yield or quality. However, additional research is needed to assess the impacts of $V$. arboreum rootstocks on productivity of mature SHB plants and longevity of the plant as a whole.

\section{Literature Cited}

Ballington, J.R. 1996. Performance of own-rooted 'Premier' rabbiteye blueberry vs. 'Premier' grafted on $V$. arboreum through three harvest seasons on a Fuquay soil. HortScience 31:749750 .

Ballington, J.R. 1998. Performance of own-rooted 'Premier' rabbiteye blueberry (Vaccinium ashei Reade) compared to 'Premier' grafted on Vaccinium arboreum Marsh (Sparkleberry) over four harvest seasons. Proc. 8th North Amer. Blueberry Res. Ext. Workers Conf. p. $178-181$.

Bell, D.J., L.J. Rowland, and F.A. Drummond. 2010. Yield variation among clones of lowbush blueberry as a function of genetic similarity and self-compatibility. J. Amer. Soc. Hort. Sci. 135:259-270.

Burkhard, N., D. Lynch, D. Percival, and M. Sharifi. 2009. Organic mulch impact on vegetation dynamics and productivity of highbush blueberry under organic production. HortScience 44:688-696.

Cantuarias-Avilés, T., F.A.A. Mourão Filho, E.S. Stuchi, S.R. Da Silva, and E. Espinoza-Núñez. 2010. Tree performance and fruit yield and quality of 'Okitsu' Satsuma mandarin grafted on 12 rootstocks. Scientia Hort. 123:318-322.

Darnell, R.L. and S.A. Hiss. 2006. Uptake and assimilation of nitrate and iron in two $\mathrm{Vacci}$ nium species as affected by external nitrate concentration. J. Amer. Soc. Hort. Sci. 131: $5-10$.

Davis, A.R., P. Perkins-Veazie, R. Hassell, A Levi, S.R. King, and X. Zhang. 2008. Grafting effects on vegetable quality. HortScience 43:1670-1672.

Ehlenfeldt, M.K. and R.B. Martin. 2002. A survey of fruit firmness in highbush blueberry and species-introgressed blueberry cultivars. HortScience 37:386-389.

Galleta, G.J. and A.S. Fish, Jr. 1971. Interspecific blueberry grafting, a way to extend Vaccinium culture to different soils. J. Amer. Soc. Hort. Sci. 96:294-298.

Harrison, R.E., J.J. Luby, and P.D. Ascher. 1993. Pollen source affects yield components and reproductive fertility of four half-high blueberry cultivars. J. Amer. Soc. Hort. Sci. 119:84-89.

Julian, J.W., B.C. Strik, H.O. Larco, D.R. Bryla, and D.M. Sullivan. 2012. Costs of establishing organic northern highbush blueberry: Impact of planting method, fertilization, and mulch type. HortScience 47:866-873.

Khah, E.M., E. Kakava, A. Mavromatis, D. Chachalis, and C. Goulas. 2006. Effect of grafting on growth 
and yield of tomato (Lycopersicon esculentum Mill.) in greenhouse and open-field. J. Appl. Hort. 8:3-7.

Kovaleski, A.P., R.L. Darnell, B. Casamali, and J.G. Williamson. 2015. Effects of timing and intensity of summer pruning on reproductive traits of two southern highbush blueberry cultivars. HortScience 50:1486-1491.

Krewer, G., M. Tertuliano, P. Andersen, O. Liburd, G. Fonsah, H. Serri, and B. Mullinix. 2009. Effect of mulches on the establishment of organically grown blueberries in Georgia. Proc. IX Intl. Symp. Vaccinium 810. p. 483-488.

Kunitake, H., H. Tsuda, R. Takagi, Y. Ohno, Y. Kurori, K. Yoshioka, T. Kage, T. Ito, and H. Komatsu. 2006. Possibility of wild blueberry Shashanbo (Vaccinium bracteatum Thunb.) as rootstock for cultivation of northern highbush blueberry in warm region. Hort. Res. Japan 5:105-110.

Liu, J., J. Li, X. Su, and Z. Xia. 2014. Grafting improves drought tolerance by regulating antioxidant enzyme activities and stress-responsive gene expression in tobacco. Environ. Expt. Bot. 107:173-179.

Lyrene, P.M. 1997. Value of various taxa in breeding tetraploid blueberries in Florida. Euphytica 94:15-22.

Lyrene, P.M. 2008. Southern highbush blueberry plant named 'Farthing'. Patent PP19,341. 14 Oct. 2008.

Lyrene, P.M. 2010. Southern highbush blueberry plant named 'FL01-173'. United States Patent 21,553. 7 Dec. 2010.

Marra, F.P., R. Lo Bianco, M. La Mantia, and T. Caruso. 2013. Growth, yield and fruit quality of
'Tropic Snow' peach on size-controlling rootstocks under dry Mediterranean climates. Scientia Hort. 160:274-282.

Maust, B.E., J.G. Williamson, and R.L. Darnell. 1999. Flower bud density affects vegetative and fruit development in field-grown southern highbush blueberry. HortScience 34:607-610.

Penella, C., S.G. Nebauer, A. Quiñones, A. San Bautista, S. López-Galarza, and A. Calatayud. 2015. Some rootstocks improve pepper tolerance to mild salinity through ionic regulation. Plant Sci. 230:12-22.

Pérez-Pérez, J.G., P. Romero, J.M. Navarro, and P. Botía. 2008. Response of sweet orange cv 'Lane late' to deficit-irrigation strategy in two rootstocks. II: Flowering, fruit growth, yield and fruit quality. Irr. Sci. 26:519-529.

Poonnachit, U. and R.L. Darnell. 2004. Effect of ammonium and nitrate on ferric chelate reductase and nitrate reductase in Vaccinium species. Ann. Bot. (Lond.) 93:399-405.

Retamales, J.B., J.M. Montecino, G.A. Lobos, and L.A. Rojas. 2008. Colored shading nets increase yields and profitability of highbush blueberries. Proc. XXVII Int. Hort. Congr. 770. p. 193-197.

Strik, B. and G. Buller. 2014. Nitrogen fertilization rate, sawdust mulch, and pre-plant incorporation of sawdust: Long-term impact on yield, fruit quality, and soil and plant nutrition in 'Elliott'. Proc. Tenth Int. Symp. Vaccinium other Superfruits 1017. p. 269-275.

Turnbull, C.G.N., J.P. Booker, and H.M.O. Leyser. 2002. Micrografting techniques for testing long-distance signalling in Arabidopsis. Plant J. 32:255-262.
Vander Kloet, S.P. 1988. The genus Vaccinium in North America. Agriculture Canada, Ottawa, Canada.

Webster, A.D. 1995. Rootstock and interstock effects on deciduous fruit tree vigour, precocity, and yield productivity. N. Z. J. Crop Hort. Sci. 23:373-382.

Williamson, J.G., P.F. Harmon, O.E. Liburd, and P. Dittmar. 2013. 2013 Florida blueberry integrated pest management guide (HS1156). University of Florida Cooperative Extension Service, Gainesville, FL.

Williamson, J.G. and P.M. Lyrene. 1995. Commercial blueberry production in Florida (SP179). University of Florida Cooperative Extension Service, Gainesville, FL.

Williamson, J.G. and E.P. Miller. 2009. Effects of fertilizer rate and form on vegetative growth and yield of southern highbush blueberry in pine bark culture. HortTechnology 19:152-157.

Williamson, J.G., J.W. Olmstead, G.K. England, and P.M. Lyrene. 2014. Southern highbush blueberry cultivars from the University of Florida (HS1245). University of Florida Cooperative Extension Service, Gainesville, FL.

Williamson, J.G., J.W. Olmstead, and P.M. Lyrene. 2012. Florida's commercial blueberry industry (HS742). University of Florida Cooperative Extension Service, Gainesville, FL.

$\mathrm{Xu}, \mathrm{C}$., Y. Ma, and H. Chen. 2014. Technique of grafting with Wufanshu (Vaccinium bracteatum Thunb.) and the effects on blueberry plant growth and development, fruit yield and quality. Scientia Hort. 176:290-296. 